\title{
Role of maternal serum ferritin as a predictive marker in intrauterine growth restriction
}

\author{
Neeta Bindal, Zeepee Godha*, Reema Kohli, V. K. Kadam
}

Department of Obstetrics \& Gynaecology, Deen Dayal Upadhaya Hospital, New Delhi, India

Received: 13 April 2015

Accepted: 09 May 2015

\author{
*Correspondence: \\ Dr. Zeepee Godha, \\ E-mail: zeepee_dr@yahoo.co.in
}

Copyright: () the author(s), publisher and licensee Medip Academy. This is an open-access article distributed under the terms of the Creative Commons Attribution Non-Commercial License, which permits unrestricted non-commercial use, distribution, and reproduction in any medium, provided the original work is properly cited.

\begin{abstract}
Background: Intrauterine growth restriction (IUGR) is most common and distressing complication for both obstetrician and neonatologist. Measurement of maternal serum ferritin has also been used as a predictive marker of increase risk of IUGR. In pregnancy, ferritin level decreases with advancing gestation. Its lowest level is seen around 30-32 weeks of gestational age after which its concentration reaches plateau level.

Methods: Total 326 antenatal women enrolled in the study. Maternal serum samples of all women were taken at $25^{\text {th }}$ week and again at 30-32 weeks in trace free mineral evacuated tubes for assessment of serum ferritin by chemiluminescence. Mean of both values was calculated.

Results: Mean ferritin value of women with average for gestational age neonates was $15.49 \mathrm{ng} / \mathrm{ml}$ and women with growth restricted neonates was $19.71 \mathrm{ng} / \mathrm{ml}$. The women with mean serum ferritin above $20 \mathrm{ng} / \mathrm{ml}$, were 6.26 times more likely to have asymmetrically growth restricted baby and 4.47 times more likely to have a symmetrically growth restricted baby when compared to women with serum ferritin value less then $<20 \mathrm{ng} / \mathrm{ml}$.

Conclusions: In our study negative correlation was found between the value of serum ferritin and neonatal birth weight. In future large randomized control trial is needed to found association between maternal serum ferritin and IUGR.
\end{abstract}

Keywords: Intrauterine growth restriction, Ferritin, Ponderal index, Alpha feto protein, Amniotic fluid lactate dehydogenase

\section{INTRODUCTION}

Intrauterine growth restriction (IUGR) is most common and distressing complication for both obstetrician and neonatologist. The term IUGR and Small for Gestational Age (SGA) is often used interchangeable. Small for gestational age is defined as fetal birth weight less than $10^{\text {th }}$ percentile for gestational age corrected for parity and gender, as per population growth chart. ${ }^{1}$ An annual incidence of around $24 \%$ of IUGR of all newborns has been reported worldwide., $40 \%$ of these are constitutionally small but healthy, $40 \%$ have asymmetrical IUGR with low ponderal index and $20 \%$ have symmetrical IUGR with normal ponderal index. ${ }^{4}$ Fetuses with restricted growth are at increased risk of many intrapartum, post natal and long term complication as fetal distress, intrapartum asphyxia, meconium aspiration, intrauterine death, postnatal hypoglycemia, neurologic developmental disorders development of type 2 diabetes, obesity, autoimmune diseases, cardiovascular diseases and hypertension in adult life. ${ }^{5-8}$ To prevent all these complication it is important to establish such markers which can predict those pregnancies very early who are at the risk of developing future IUGR. Recently many studies have highlighted the role of many 
biomolecules as markers of IUGR like leptin, adiponectin, endothelin-1, lactate dehydrogenase, sendoglin, soluble FMS tyrosine kinase receptor 1(sFTL1), pregnancy associated plasma protein,metastin. ${ }^{9-16}$ Apart from being expensive, laboratories at majority of centers are not equipped with facilities of measurements of these markers. Measurement of maternal serum ferritin has also been used as a predictive marker of increase risk of IUGR. ${ }^{17}$ Ferritin is a globular protein complex consisting of 24 protein subunits and is the primary intracellular iron storage protein. It is an acute phase protein and its serum concentration increases in stresses like anoxia and infection. ${ }^{18,19}$ In pregnancy ferritin level decreases with advancing gestation. ${ }^{20}$ Its lowest level is seen around 3032 weeks of gestational age after which its concentration reaches plateau level. ${ }^{20}$

\section{METHODS}

This was a longitudinal prospective study conducted in the department of obstetrics and gynaecolgy in our hospital between January 2011 and December 2012. Total 326 antenatal women visiting the antenatal clinic were enrolled in the study at $25^{\text {th }}$ week. Exclusion criteria were BMI <18, placental abnormalities like velamentous insertion, antepartum hemorrhage, multiple pregnancies, patients with acute infection, patients with positive CRP, raised TLC count, congenital malformation, and fetuses with chromosomal or genetic syndrome. Gestational age was defined as completed weeks from the onset of last menstrual period, if there was mismatch between the dates and USG reports by more than two weeks then the ultrasonographic dating (first trimester) was considered for calculating gestational age. Maternal serum samples of all women were taken at $25^{\text {th }}$ week and again at 30-32 weeks in trace free mineral evacuated tubes for assessment of serum ferritin by chemiluminescence. Mean of both values was calculated. Hemoglobin was estimated of all women at the time of inclusion in the study and again in late third trimester. All patients were serially followed up till delivery. Mode of delivery, gestational age at delivery, birth weight and crown rump length of all neonates were assessed at time of birth. Ponderal index of all neonates with fetal growth retardation was calculated. Rohrer's ponderal index is defined as 100 times birth weight (in grams) divided by the cube of birth weight. ${ }^{21}$ Based on the above measurement babies were divided in two groups. In group A neonates with birth weight more than or equal to the $10^{\text {th }}$ percentile for corresponding gestational age were included as average for gestational age. In group B neonates with birth weight less than $10^{\text {th }}$ percentile for corresponding gestational age were included as small for gestational age. Group B was again divided in two parts, group B1 included women having neonates with ponderal index less than 2 (between 29 to 37 weeks) and less than 2.25 (>37 weeks) as asymmetrical FGR, group B2 included neonates with ponderal index more or equal to2.25 at birth as symmetrical FGR. ${ }^{21,22}$ Depending upon maternal serum ferritin value women were divided in three groups. Group 1 included women with mean serum ferritin $<10 \mathrm{ng} / \mathrm{ml}$, group 2 included women with mean serum ferritin value between $10 \mathrm{ng} / \mathrm{ml}-20 \mathrm{ng} / \mathrm{ml}$ and group 3 consisted of women with mean serum ferritin value $>20$ $\mathrm{ng} / \mathrm{ml}$. Sensitivity, specificity, positive and negative predictive value at various cut off of serum ferritin were calculated and ROC curve was analyzed (Table 3 ).

\section{RESULTS}

There were total 326 women included in the study. 36 women lost to follow up. Out of all cases that were followed up till term 2 patients had sudden intrauterine death, 3 patients developed jaundice, 8 patients developed preeclampsia, 20 patients developed pre-term labor. These high risk pregnancies were excluded from study to remove any confounding factor from the study and finally data from 257 women were taken for analysis. There were total 204 (79.37\%) women in group A having average for gestational age neonates, and 53 (20.62\%) women in group B having neonates small for gestational age. In group B1 asymmetrically growth restricted were $30(11.67 \%)$ and symmetrically growth restricted were 23 (8.94\%).The mean age of women in group A was 22.9 years and in group B was 23.1 years. The difference between mean ages of both groups was not significant statistically. Mean gestational age of delivery in group A was 38.03 weeks, in group B was 37.91 weeks. Mean birth weight in group A was $2674.41 \mathrm{gm}$, and in group B was $2199.81 \mathrm{gm}$. The difference in mean birth weight between two group was statistically significant $(\mathrm{P}<0.05)$. Mean ferritin value of group A was $15.49 \mathrm{ng} / \mathrm{ml}$ and that of group B was $19.71 \mathrm{ng} / \mathrm{ml}$. There was statistically significant difference between mean ferritin value of two group $(\mathrm{P}=0.03)$. The mean hemoglobin in group $\mathrm{A}$ was $10.46 \mathrm{gm} \%$ and in group B was $11.91 \%$, the difference between two was statistically significant $(\mathrm{P}<0.05)$.

Table 1: Clinical characteristics and their values of two different groups.

\begin{tabular}{|c|c|c|c|}
\hline Characteristics & Group A & Group B & $P$ value \\
\hline $\begin{array}{l}\text { Number of } \\
\text { women }\end{array}$ & $\begin{array}{l}204 \\
(79 \%)\end{array}$ & $\begin{array}{l}53 \\
(20.6 \%)\end{array}$ & \\
\hline Mean age (years) & 22.94 & 23.1 & $\begin{array}{l}0.83 \\
\text { (not significant) }\end{array}$ \\
\hline $\begin{array}{l}\text { Period of } \\
\text { gestation at } \\
\text { delivery }\end{array}$ & 38.03 & 37.91 & \\
\hline $\begin{array}{l}\text { Mean birth } \\
\text { weight }(\mathrm{gm})\end{array}$ & 2674.9 & 2199.8 & $\begin{array}{l}<0.05 \\
\text { (significant) }\end{array}$ \\
\hline $\begin{array}{l}\text { Mean ferritin } \\
\text { level }(\mathrm{ng} / \mathrm{ml}) \\
95 \% \mathrm{CI}\end{array}$ & $\begin{array}{l}15.49 \\
13.67- \\
17.32\end{array}$ & $\begin{array}{l}19.71 \\
16.90- \\
22.54\end{array}$ & $\begin{array}{l}<0.03 \\
\text { (significant) }\end{array}$ \\
\hline $\begin{array}{l}\text { Mean } \\
\text { hemoglobin } \\
\text { (gm\%) } \\
95 \% \text { CI }\end{array}$ & $\begin{array}{l}10.46 \\
10.32- \\
10.68\end{array}$ & $\begin{array}{l}11.91 \\
11.23- \\
12.5\end{array}$ & $\begin{array}{l}<0.05 \\
\text { (significant) }\end{array}$ \\
\hline
\end{tabular}


As shown in Table 2, patients were divided in three groups depending on the serum ferritin value. The above data shows that the maximum percentage of growth restricted babies is seen in the subgroup of women who had mean serum ferritin value of $>20 \mathrm{ng} / \mathrm{ml}$ during pregnancy. The data above depict that women with mean serum ferritin above $20 \mathrm{ng} / \mathrm{ml}$, were 6.26 times more likely to have asymmetrically growth restricted babies and 4.47 times more likely to have a symmetrically growth restricted babies when compared to women with serum ferritin value less then $<20 \mathrm{ng} / \mathrm{ml}$. The analysis was statistically significant $\mathrm{P}<0.0001$ for asymmetrical growth restriction as an outcome and $\mathrm{P}<0.05$ for symmetrical growth restriction as an outcome).

Table 2: Distribution of women according to different range of mean serum ferritin value and their association.

\begin{tabular}{|c|c|c|c|c|c|c|c|c|c|}
\hline $\begin{array}{l}\text { Mean serum } \\
\text { ferritin } \\
\text { values }\end{array}$ & $\begin{array}{l}\text { Asymmetrically } \\
\text { growth } \\
\text { restricted } \\
\text { babies }\end{array}$ & $\begin{array}{l}\text { Odds } \\
\text { ratio }\end{array}$ & CI & P value & $\begin{array}{l}\text { Symmetrically } \\
\text { growth } \\
\text { restricted } \\
\text { babies }\end{array}$ & $\begin{array}{l}\text { Odds } \\
\text { ratio }\end{array}$ & CI & $P$ value & $\begin{array}{l}\text { A verage } \\
\text { for } \\
\text { gestational } \\
\text { babies }\end{array}$ \\
\hline$>20 \mathrm{ng} / \mathrm{ml}$ & $21(69 \%)$ & 6.26 & $2.86-13.69$ & $<0.0001$ & $10(50 \%)$ & 4.47 & $1.66-11.99$ & 0.0029 & $45(21.8 \%)$ \\
\hline $10-20 \mathrm{ng} / \mathrm{ml}$ & 2 & 1.0 & & & 6 & 1.0 & & & 72 \\
\hline$<10 \mathrm{ng} / \mathrm{ml}$ & 8 & 1.0 & & & 4 & 1.0 & & & 89 \\
\hline
\end{tabular}

Table 3: Data showing sensitivity, specificity, positive predictive value, negative predictive value of various serum cut offs to predict fetal growth restriction.

\begin{tabular}{|lllllll|}
\hline Serum ferritin cut off & Sensitivity & Specificity & + LR & -LR & + PV & -PV \\
\hline$\geq 4.02$ & 100.0 & 0.00 & 1.00 & & 20.2 & \\
\hline$>4.5$ & 92.31 & 6.31 & 0.99 & 1.22 & 19.9 & 76.5 \\
\hline$>6.95$ & 92.31 & 19.90 & 1.15 & 0.39 & 22.5 & 91.1 \\
\hline$>7.1$ & 84.62 & 19.90 & 1.06 & 0.77 & 21.5 & 83.7 \\
\hline$>9.91$ & 84.62 & 43.20 & 1.49 & 0.36 & 27.3 & 91.8 \\
\hline$>10.32$ & 69.23 & 43.20 & 1.22 & 0.71 & 23.5 & 84.8 \\
\hline$>13.4$ & 69.23 & 60.68 & 11.76 & 0.51 & 30.8 & 88.7 \\
\hline$>13.87$ & 61.54 & 60.68 & 1.57 & 0.63 & 28.3 & 86.2 \\
\hline$>20.2$ & 61.54 & 80.10 & 3.09 & 0.48 & 43.8 & 89.2 \\
\hline$>21.1$ & 53.85 & 82.04 & 3.00 & 0.56 & 43.1 & 87.6 \\
\hline$>21.55$ & 46.15 & 82.04 & 2.57 & 0.66 & 39.3 & 85.8 \\
\hline$>21.94$ & 38.46 & 83.98 & 2.40 & 0.73 & 37.7 & 84.4 \\
\hline$>23.2$ & 38.46 & 85.92 & 2.73 & 0.72 & 40.8 & 84.7 \\
\hline$>23.6$ & 15.38 & 85.92 & 1.09 & 0.98 & 21.6 & 80.1 \\
\hline$>28.14$ & 15.38 & 94.17 & 2.64 & 0.90 & 40.0 & 81.5 \\
\hline$>39.42$ & 0.00 & 94.17 & 0.00 & 1.06 & 0.0 & 78.9 \\
\hline$>83.1$ & 0.00 & 100.00 & & 1.00 & & 79.8 \\
\hline
\end{tabular}

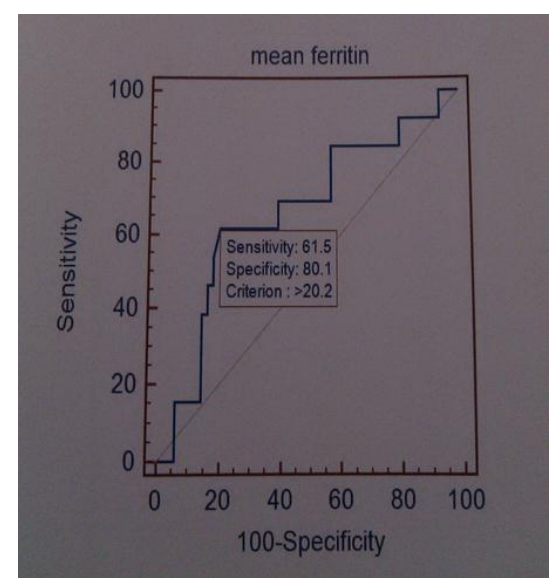

Figure 1: ROC curve.
ROC curve (Figure 1) showed that serum ferritin value at $20.2 \mathrm{ng} / \mathrm{ml}$ was associated with highest Yuden's index which means that it can be taken as a cut off for screening antenatal patients for development of fetal growth restriction with $61.5 \%$ sensitivity and $80.1 \%$ specificity.

\section{DISCUSSION}

Fetal growth restriction is not only short term worry during antenatal period but also have long term effects affecting neonatal period, childhood and even adulthood also. Present study reports a $20 \%$ rate of growth restricted babies which is higher than most of other studies but comparable to study of $\mathrm{J}$. Hou et al. which reported $23.2 \%$ incidence in their study. ${ }^{2}$ Table 4 shows various neonatal outcomes studied in different studies. 
Table 4: Comparison of results of our study with other studies.

\begin{tabular}{|c|c|c|c|c|c|}
\hline Year & Name & $\begin{array}{l}\text { Serum ferritin cut } \\
\text { off for prediction } \\
\text { as per ROC curve }\end{array}$ & Sensitivity & Specificity & $\begin{array}{l}\text { Odds of growth restriction with serum } \\
\text { ferritin above the defined cut off }\end{array}$ \\
\hline 2010-2011 & Nimanja Vinjevac et al. ${ }^{17}$ & $13.6 \mathrm{ng} / \mathrm{ml}$ & $64.7 \%$ & $91.7 \%$ & $>15 \mathrm{ng} / \mathrm{ml}$ OR 4.5 \\
\hline 1996 & J. Hou et al. ${ }^{23}$ & $13 \mathrm{ng} / \mathrm{ml}$ & & & $>13 \mathrm{ng} / \mathrm{ml}$ OR 4.5 for low birth weight \\
\hline 2011 & Present study & $20.2 \mathrm{ng} / \mathrm{ml}$ & $61.5 \%$ & $80.1 \%$ & $\begin{array}{l}>20.2 \text { OR } 6.26 \text { for asymmetric restriction } \\
\text { and } 4.47 \text { for symmetric }\end{array}$ \\
\hline
\end{tabular}

In our study negative correlation was found between the value of serum ferritin and neonatal birth weight. The coefficient of correlation was -0.36 (significant) which was higher than study of Nemanja Visnjevac et al. (-0.24, significant). ${ }^{17}$ In our study cut off point is $20.2 \mathrm{ng} / \mathrm{ml}$ (sensitivity $64.7 \%$, specificity $91.7 \%$ ) while in the study of Nimanja Vinjevac et al. cut off was $13.6 \mathrm{ng} / \mathrm{ml}$ (sensitivity $64.7 \%$, specificity 91.75 ) which is lower than our study.
The Table 5 shows the comparison between various other markers and serum ferritin as a predictor of fetal growth restriction. Although amniotic fluid LDH value boasts of a better sensitivity and specificity but it is more invasive, costly and associated with greater procedural side effects when compared to serum ferritin assessment. ${ }^{12}$ Elevated level of serum alpha feto protein $(>2.5 \mathrm{Mom})$ is also associated with intra uterine growth restriction with odds ratio ranging from 1.6-4.0, But no specific treatment protocol was suggested for its increase level. ${ }^{24}$

Table 5: Comparison between various other marker with maternal serum ferritin.

\begin{tabular}{|c|c|c|c|c|c|}
\hline Study & $\begin{array}{l}\text { Name of } \\
\text { predictor }\end{array}$ & Measured in & $\begin{array}{l}\text { Sensitivity } \\
\text { as a } \\
\text { predictor }\end{array}$ & Specificity & $\begin{array}{l}\text { PPV as a } \\
\text { predictor }\end{array}$ \\
\hline Audibert et al. ${ }^{28}$ & Alpha feto protein & Serum; mid trimester & $40 \%$ & $82 \%$ & $43 \%$ \\
\hline Borna $\mathrm{S}$ et al. $^{12}$ & $\mathrm{LDH}$ & Amniotic fluid; mid trimester & $87.5 \%$ & $82.4 \%$ & \\
\hline Present study & ferritin & Serum; third trimester & $61.5 \%$ & $80.1 \%$ & $43.8 \%$ \\
\hline
\end{tabular}

Fetal growth is regulated by the balance between fetal nutrient demand and maternal-placental nutrient supply. Iron deficiency has its known deleterious effect in pregnancy but iron loading may be associated with oxidative damage to cells and tissues. It has been shown in various studies that Lower level of Transferritin receptor expression in placenta is associated with preeclampsia and IUGR. ${ }^{25,26}$ This can lead to decrease extraction of iron by placenta from maternal serum leading to increase maternal serum ferritin. Placental isoferritin levels also found to be decrease in IUGR and preeclampsia in some studies. ${ }^{27}$ This iron deficiency lead to increase in fetal coticotropins and fetal cortisol, causes inhibition of fetal growth. In present study smoking, hypertension, very low BMI $<18$ has been taken as exclusion criteria to negotiate their confounding effect on the value of maternal serum ferritin; there by evaluating the role of solely serum ferritin on intra uterine growth restriction.

In future large randomized control trial is needed to found association between mataernal serum ferritin and IUGR, including various maternal hematological indices with placental and cord blood ferritin level and the results could help in prevention of unknown adverse effect of iron supplementation in pregnancies.
Funding: No funding sources

Conflict of interest: None declared

Ethical approval: Not required

\section{REFERENCES}

1. Battaglia FC, Lubchenco LO. A practical classification of newborn infants by weight and gestational age. J Pediatr. 1967;71:159-63.

2. Deonis M, Blossner M, Villar J. Levels and patterns of intrauterine growth retardation in developing countries. Eur J Clin Nutr. 1998;52:S83-93.

3. UNICEF. United Nations Children's Fund and World Health Organization. Low birth weight. In: UNICEF, eds. Country, Regional and Global Estimates. New York, USA: UNICEF; 2004.

4. Ross MG. Fetal growth restriction, 2008. Available at: http://emedicine.medscape.com/article/261226overview. Accessed 8 March 2013.

5. Mcintire DD, Bloom SL, Casey BM. Birth weight in relation to morbidity and mortality among newborn infants. N Engl J Med. 1999;340(16):1234-8.

6. Roth S, Chang TC, Robson S. The neurodevelopmental outcome of term infants with different intrauterine growth characteristics. Early Hum Dev. 1999;55(1):39-50. 
7. Cnattingius S, Haglund B, Kramer MS. Differences in late fetal death rates in association with determinants of small for gestational age fetuses: population based cohort study. BMJ. 1998;316:14378.

8. Shankaran S, Das A, Bauer CR. Fetal origin of childhood disease: intrauterine growth restriction in term infants and risk for hypertension at 6 years of age. Arch Pediatr Adolesc Med. 2006;160 (9):97781.

9. Laivuori H, Gallaher MJ, Collura L, Crombleholme WR, Markovic N, Rajakumar A, et al. Relationships between maternal plasma leptin, placental leptin mRNA and protein in normal pregnancy, preeclampsia and intrauterine growth restriction without preeclampsia. Mol Hum Reprod. 2006;12(9):551-6.

10. Kyriakakou M, Malamitsi-Puchner A, Militsi $H$. Leptin and adiponectin concentrations in intrauterine growth restricted and appropriate for gestational age fetuses, neonates, and their mothers. Eur J Endocrinol. 2008;158:343-8.

11. Al-Shahat Nezar M, Abd El-Baky AM, Al-Said Soliman O, Abdel-Hady HA, Hammad AM, AlHaggar MS. Endothelin-1 and leptin as markers of intrauterine growth restriction. Indian $\mathrm{J}$ Pediatr. 2009;76(5):485-8.

12. Borna S, Abdollahi A, Mirzaei F. Predictive value of mid-trimester amniotic fluid high-sensitive Creactive protein, ferritin, and lactate dehydrogenase for fetal growth restriction year. Indian J Pathol Microbiol. 2009;52(4):498-500.

13. Wang CN, Chang SD, Peng HH, Lee YS, Chang YL, Cheng PJ, et al. Change in amniotic fluid levels of multiple anti-angiogenic proteins before development of preeclampsia and intrauterine growth restriction. J Clin Endocrinol Metab. 2010;95(3):1431-41.

14. Proctor LK, Toal M, Keatingt S, Chitayat D, Okun $\mathrm{N}$, Windrim RC, et al. Placental size and the prediction of severe early-onset intrauterine growth restriction in women with low pregnancy-associated plasma protein-A. Ultrasound Obstet Gynecol. 2009;34:274.

15. Armstrong RA, Reynolds RM, Leask R, Shearing $\mathrm{CH}$, Calder AA, Riley SC. Decreased serum levels of kisspeptin in early pregnancy are associated with intra-uterine growth restriction and preeclampsia. Prenat Diagn. 2009;29(10):982-5.

16. Zhang J, Merialdi M, Platt LD. Defining normal and abnormal fetal growth: promises and challenges. Am J Obstet Gynecol. 2010;202(6):522-8.

17. Nemanja V, Ljiljana MS, Aleksandar C, Jovana V, Dragan S. Blood ferritin levels in pregnant women and prediction of the development of fetal intrauterine growth restriction. J Med Biochem. 2011;30:m317-22.

18. Ong D, Wang L, Zhu Y, Ho B, Ding J. The response of ferritin to LPS and acute phase of Pseudomonas infection. J Endotoxin Res. 2005;11(5):267-80.

19. Larade K, Storey KB. Accumulation and translation of ferritin heavy chain transcripts following anoxia exposure in amarine invertebrate. J Experiment Biol. 2004;207(Pt8):1353.

20. Lee JL, Kang SA, Kim SK, Lim HS. A cross sectional study of maternal iron status of Korean women during pregnancy. Nutr Res. 2002;22(12):1277-88.

21. Dure SA, Fehmina A. Ponderal index of low birth weight babies - a hospital based study. J Pak Med Assoc. 2005 Jun;55(6):229-31.

22. Mohan M, Prasad SR, Chellani HK, Kapani V. Intrauterine Growth curves in North Indian Babies: weight, length, ponderal index. Indian Pediatr. 1990;27:43-51.

23. Hou J, Cliver S, Tramura T, Johnston K, Goldenberg R. Maternal serum ferritin and fetal growth. Obstet Gynecol. 2000;95:447-52.

24. Gagnon A, Wilson RD, Audibert F, Allen VM, Blight C, Brock JA, et al. Obstetrical complication associated with abnormal maternal serum marker analytes. SOGC Technical Update No. 217. J Obstet Gynaecol Can. 2008 Oct;30(10):918-49.

25. Mandò $\mathrm{C}$, Tabano $\mathrm{S}$, Colapietro $\mathrm{P}$, Pileri $\mathrm{P}$, Colleoni $\mathrm{F}$, Avagliano L, et al. Transferrin receptor gene and protein expression and localization in human IUGR and normal term placentas. Placenta. 2011 Jan;32(1):44-50.

26. Khatun R, Wu Y, Kanenishi K, Ueno M, Tanaka S, Hata $T$, et al. Immunohistochemical study of transferrin receptor expression in the placenta of preeclamptic pregnancy. Placenta. 2003 SepOct;24(8e9):870.

27. Zhu Ying, Wang Zehua, Xiong Guirong. Placental isoferritin in pathogensis of preeclampsia and/or intrauterine growth retardation and its earlier predictive value. J Huazhong Univ Sci Technol (Med Sci). 2003;23(1):48-51.

28. Audibert F, Benchimol Y, Benattar C, Champagne C, Frydman R. Prediction of preeclampsia or intrauterine growth restriction by second trimester serum screening and uterine velocimetry. Fetal Diagn Ther. 2005 Jan-Feb;20(1):48-53.

DOI: $10.18203 / 2320-1770 . i j \operatorname{cog} 20150096$

Cite this article as: Bindal N, Godha Z, Kohli R, Kadam

$\mathrm{KV}$. Role of maternal serum ferritin as a predictive marker in intrauterine growth restriction. Int J Reprod Contracept Obstet Gynecol 2015;4:804-8. 